\title{
THE RELATION AMONG THE PHYSICAL ACTIVITY LEVEL DURING LEISURE TIME, ANTHROPOMETRY, BODY COMPOSITION, AND PHYSICAL FITNESS OF WOMEN UNDERWENT OF BARIATRIC SURGERY AND AN EQUIVALENT GROUP WITH NO SURGERY
}

Relação entre nível de atividade física em lazer, antropometria, composição corporal e aptidão física de mulheres submetidas à cirurgia bariátrica e um grupo equivalente não operado

Caio Machado de Oliveira TERRA ${ }^{5,6}$, Caroline Ferraz SIMÕES ${ }^{2,6}$, Anselmo Alexandre MENDES ${ }^{2,6}$, Ronano Pereira OLIVEIRA $^{2,3,6}$, Rafaela Pilegi DADA ${ }^{2,4,6}$, Victor Hugo de Souza MENDES ${ }^{1,6}$, João Carlos LOCATELI ${ }^{1,6}$ e Nelson Nardo-Junior ${ }^{1,6}$

From the 'Departamento de Educação Física, Universidade Estadual de Maringá, Maringá, PR 2Programa de Pós-graduação Associado UEM/ UEL Universidade Estadual de Maringá, Maringá, PR; ${ }^{3}$ nstituto Federal do Tocantins, Araguatins, TO; PR; ${ }^{3}$ Instituto Federal do Tocantins, Araguatins, TO;
${ }^{4}$ Secretaria de Educação, Prefeitura Municipal de Marialva. Marialva, PR; ${ }^{5}$ Programa de Pós-graduação Interdisciplinar em Ciências da Saúde, Universidade Federal de São Paulo, Santos, SP. ${ }^{6}$ Núcleo de Estudos Multiprofissional da Obesidade, Universidade Estadual de Maringá, Maringá, PR, Brasil ('Physical Education Department, State University of Maringá, Maringá, PR: 2Post-graduate program UEM/UEL, State University of Maringá, Maringá, PR. ${ }^{3}$ Eederal Tocantins Institute, Marialva, PR; ${ }^{5}$ Interdisciplinary Health Sciences Postgraduate 'Program, Federal University of São Paulo, Santos, SP; ${ }^{6}$ Multidisciplinary Center of Obesity Studies, State University of Maringá, Maringá,PR), Brazil.

HEADINGS - Obesity. Bariatric surgery.

Physical fitness and physical activity.
ABSTRACT - Background: Bariatric surgery is an alternative to the obesity treatment. Aim: To compare anthropometric variables such as body composition and physical fitness of those who performed Roux-en-Y gastric bypass. Methods: Were evaluated 108 women. They were subdivided in three groups: those who performed the bariatric surgery by private health insurance (SAS, $n=36)$; by the public health care (SUS, $n=36)$, and an equivalent group which did not perform the surgery (NO, $\mathrm{n}=36)$. Were performed physical fitness, anthropometric and body composition tests. Was evaluated the level of physical activity during the leisure period. Results: Statistically significant differences were observed between the groups sedentary operated $(n=28)$ and sedentary non-operated $(n=13)$ on anthropometry and fat percentage, being the highest indexes in the group operated. Conclusion: The level of physical activity showed a positive influence related to anthropometric variables, body composition of the individuals who performed the bariatric surgery when compared to the ones non-operated.

\section{Correspondence:}

Caio Machado de Oliveira Terra

E-mail: caio.mo.terra@gmail.com

Financial source: $\mathrm{CNPq}$

Conflict of interest: none

Received for publication: 20/06/2017 Accepted for publication: 19/09/2017

DESCRITORES - Obesidade. Cirurgia bariátrica. Aptidão física e nível de atividade física.
RESUMO - Racional: Observa-se o aumento da realização da cirurgia bariátrica como alternativa de tratamento para obesidade. Objetivo: Comparar a antropometria, composição corporal e aptidão física de pacientes submetidos ao bypass gástrico em Y-de-Roux. Métodos: Foram avaliadas 108 mulheres subdivididas em: operadas por convênios de saúde particulares (SAS, n=36), Sistema Único de Saúde (SUS, n=36) e um grupo equivalente não operado (NO, $\mathrm{n}=36)$. Foram realizados testes de aptidão física, antropometria e composição corporal, e avaliado nível de atividade física no lazer. Resultados: Não houve diferença estatisticamente significativa nas variáveis estudadas entre os grupos SAS, SUS e NO. Observaram-se diferenças estatisticamente significativas entre os grupos operados sedentários $(n=28)$ e não operados sedentários $(n=13)$ na antropometria e percentual de gordura, sendo ao grupo operado os índices mais altos. Conclusões: O nível de atividade física apresentou influência positiva sobre as variáveis antropométricas, de composição corporal de pacientes submetidos à cirurgia bariátrica quando comparados aos não operados. 
consists of skeletal muscle mass and its lost reflects significantly on the decreasing of both static and dynamic muscle strength (physical fitness important aspects), and consequently decreasing the individuals functional capacity ${ }^{11,19,28}$.

Nevertheless, there are evidences that regular physical activity practice promotes an enhancement on the physical fitness parameters, and it contributes directly to the functional capacity and quality of life of the operated individuals ${ }^{14,21,25}$. Healthy lifestyle, including a healthy food intake and regular physical activity practice, contributes not only to the maintenance of the positive results acquired with the surgery, but also to the general health conditions of these patients ${ }^{1}$.

Thus, the aim of this study was to compare the anthropometry, body composition, and physical fitness of patients underwent of bariatric surgery with non-operated individuals, dividing them in two distinct groups: active and sedentary.

\section{METHODS}

Were assessed 320 women that presented the requirements of the pairing criteria by the body mass index $\left( \pm 2 \mathrm{~kg} / \mathrm{m}^{2}\right)$ and age ( \pm 10 years). Were excluded from the original sample 192 individuals that not filled the physical activity level questionnaire ${ }^{18}$. Therefore the 108 women that were fit in both inclusion and exclusion criteria were divided into three groups. Two groups (SUS and SAS) represented the individuals operated with the Roux-en-Y gastric bypass, from 2000 to 2012, by the public health care (SUS) or particular insurances (SAS) respectively. A third non-operated equivalent control group (NO) underwent to the same assessments applied to other two groups.

The patients were invited to participate of the meetings, where was elucidated the research details, and asked to sign the free and informed consent previously approved by the local Ethics Committee (protocol 412/2008).

To the individuals included in the sample were performed anamneses to collect the following data: age, procedure date, and data related to the bariatric surgery. After that, was applied a physical activity level questionnaire, proposed by Larsson et al. ${ }^{17}$ as well anthropometric, body composition and physical fitness assessments.

\section{Anthropometric and body composition evaluations}

The anthropometric and body composition measures were taken at the Multidisciplinary Center of Obesity Studies. The body mass was assessed by an multifrequency bioelectrical impedance analyzer (Octapolar, Inbody 520 model, Korea) with an scale attached and precision of $100 \mathrm{~g}$, with maximal weight capacity of $250 \mathrm{~kg}$. The patients were advised to follow rigorously the protoco proposed by Heyward ${ }^{13}$. The height was verified through a wall mounted stadiometer with precision of $0.1 \mathrm{~mm}$.

\section{Physical fitness evaluation}

The patients underwent to a submaximal effort test, 6MWT (6 min walking test) used as an indicative of the cardiorespiratory fitness and functional capacity. The test started after 5 min rest in the sitting position to the maintenance of the resting physiological responses. A hall was used to establish a $50 \mathrm{~m}$ distance, in which the individuals were instruct to go through the longest distance possible in $6 \mathrm{~min}$. An experient instructor controlled the time, and the patients should stop completely after the buzzer, so the exact distance was recorded for each individual. Encouragement phrases were used each minute to make the individuals reach their best ${ }^{2,27}$

\section{Flexibility}

The test "sit and reach" was performed using the Wells chair to flexibility assessment. The patients were instructed to keep the soles of the feet in contact with the chair, with both arms and legs outstretched. The arms on the box surface with the hands folded with the top of the fingers united and hands turned down, making contact with the chair. They should reach the longest distance possible going through it slowly, with no bumps, standing in their longest distance for at least $2 \mathrm{~s}$. The best of three attempts was recorded ${ }^{9}$

\section{Grip strength test}

A manual dynamometer was used (T-18, Smedley III) to perform the grip strength test through the following protocol: lateral legs stretching, arms in the orthostatic position, forearms and fists in a neutral position at the same line. The individual should make the maximal strength with their fingers to move the equipment bar. Three attempts were repeated and the best one was recorded ${ }^{9}$

\section{Statistical analysis}

To the descriptive and inferential data analysis was used the statistic package IBM, Software SPSS 20.0 version, and the normality data was tested and the significance level was established in $\leq 0.05$ ). The data distribution was made by the Shapiro-Wilk test, and the following statistic tests: ANOVA One-Way, Kruskal-Wallis and Post-Hoc of Bonferroni were used the comparison between the three groups (SUS, SAS and NO). The tindependent test and $U$ of Man-Whitney compared the operated active and sedentary group, as well the Pearson's correlation. Were considered in the data analysis only the patients that correctly answered the level of physical activity questionnaire.

\section{RESULTS}

The Table 1 presents the results in mean and standard deviation of the characterization variables. The tests did not showed any statistically significant difference in none of the variables analyzed, ensuring the groups homogeneity.

TABLE 1-Sample characterization subdivided and comparison of anthropometric, body composition and physical fitness of the groups SAS, SUS and NO

\begin{tabular}{|c|c|c|c|c|c|c|c|}
\hline Variables & SUS & $n=36)$ & SAS ( & $n=36)$ & NO ( & n=36) & $p$ \\
\hline Age (years) & 50.0 & $(17.00)$ & 49.5 & (18.25) & 44.0 & (14.5) & .501 \\
\hline Body mass $(\mathrm{kg})$ & 72.45 & (14.77) & 78.45 & $(15.20)$ & 71.75 & (19.95) & .119 \\
\hline Height (m) & 1.59 & \pm 0.07 & 1.59 & \pm 0.06 & 1.60 & \pm 0.07 & .821 \\
\hline $\mathrm{BMI}\left(\mathrm{kg} / \mathrm{m}^{2}\right)$ & 26.93 & (6.93) & 30.64 & $(6.20)$ & 28.25 & $(8.20)$ & .128 \\
\hline$W C(\mathrm{~cm})$ & 82.65 & (15.30) & 84.00 & (13.63) & 85.75 & (16.6) & .453 \\
\hline $\mathrm{HC}(\mathrm{cm})$ & 103.0 & (15.42) & 111.65 & $(13.45)$ & 105.25 & (18.17) & .053 \\
\hline $\mathrm{F} \%$ & 36.39 & \pm 8.50 & 40.68 & \pm 6.78 & 39.1 & \pm 7.56 & .060 \\
\hline SMM (kg) & 23.95 & $(3.60)$ & 24.45 & (5.18) & 24.45 & $(4.85)$ & .840 \\
\hline $\mathrm{GS}(\mathrm{kg} / \mathrm{f})$ & 27.00 & 6.30 & 25.63 & \pm 5.30 & 25.62 & \pm 4.68 & .225 \\
\hline FLEX $(\mathrm{cm})$ & 24.50 & 15.75 & 20.14 & \pm 9.40 & 21.61 & \pm 6.69 & .148 \\
\hline 6MWT (m) & 499.68 & 91.00 & 499.7 & \pm 65.92 & 521.4 & \pm 72.41 & .297 \\
\hline
\end{tabular}

* =Statistically significant difference; $\mathrm{p}=\leq 0,05 ; \mathrm{BMI}=$ body mass index; $\mathrm{WC}=$ wais circumference; $\mathrm{HQ}=$ hip circumference; $\mathrm{F} \%$ =fat percentage; $\mathrm{SMM}=$ skeletal muscle mass; GS=grip strength; FLEX=wells chair sit and reach test; $6 \mathrm{MWT}=6$-minutes walking test; FLEX=flexibility; time since surgery $S U S=38,0$ (30); time since surgery $\mathrm{SAS}=61,0(114,5)$. Anova one-away e Kruskal-Wallis

TABLE 2 - Correlation among anthropometric, body composition and health-related physical activity variables

\begin{tabular}{|c|c|c|c|c|c|c|c|c|c|}
\hline & Mass & BMI & WC & $\mathrm{HC}$ & F\% & SMM & GS & FLEX & 6MWT \\
\hline BM & 1 & $.916^{\star \star \star}$ & $.792^{\star \star \star}$ & $.704^{\star \star \star}$ & $678^{\star \star \star}$ & 430 ** & $260 * *$ & $-.131^{\star}$ & $-.213^{*}$ \\
\hline BMI & & 1 & $.831^{\star \star \star}$ & $.670^{\star \star \star}$ & $801^{\text {*** }}$ & $293^{*}$ & $092^{*}$ & $-.094^{*}$ & $-.367^{\star *}$ \\
\hline WC & & & 1 & $.515^{\star \star \star}$ & $649 * \star *$ & $238^{*}$ & $119^{*}$ & $-.167^{*}$ & $-.269 *$ \\
\hline $\mathrm{HC}$ & & & & 1 & $571^{\star \star *}$ & $243^{*}$ & $234^{*}$ & $013^{*}$ & $-.103^{*}$ \\
\hline $\mathrm{F} \%$ & & & & & 1 & $-.120^{*}$ & $-.110^{*}$ & $-.168^{\star \star}$ & $-.445^{\star *}$ \\
\hline SMM & & & & & & 1 & $278^{*}$ & $-.101^{\star \star}$ & $.159^{*}$ \\
\hline GS & & & & & & & 1 & $-.014^{*}$ & $.365^{\star \star}$ \\
\hline FLEX & & & & & & & & 1 & $.017^{*}$ \\
\hline TC6M & & & & & & & & & 1 \\
\hline
\end{tabular}

*Weak correlation; **moderate correlation; ***Strong correlation; BM=body mass; $\mathrm{BMI}=$ body mass index; $\mathrm{WC}=$ waist circumference; $\mathrm{HQ}=$ hip circumference; $\mathrm{F} \%=$ fat percentage; $\mathrm{SMM}=$ skeletal muscle mass; $\mathrm{GS}=$ grip strength; $6 \mathrm{MWT}=6$ min walking test; FLEX=flexibility; $n=72$. Pearson. 
Was not observed any statistically significant difference between the SAS and SUS group regarding the physical fitness variables and their respective characterizations, being considered equivalent and subdivided according to the level of physical fitness during leisure time. Thus, were performed comparisons of the anthropometric, body composition, and physical fitness variables according to the sedentary group, comparison of the operated group $(n=28)$ and $N O(n=13)$ and between the physically actives operated $(n=35)$ and NO $(n=15)$.

TABLE 3 - Comparison of the patients underwent to bariatric surgery and an equivalent non-operated group divided in physically active and sedentary during their leisure time

\begin{tabular}{|c|c|c|c|c|c|c|c|c|c|c|c|}
\hline & Age & BM & BMI & WC & HC & F\% & SMM & GS & FLEX & $6 M W T$ \\
\hline $\begin{array}{c}\text { Sed. } \\
\text { Opera }\end{array}$ & 51.0 & 83.1 & 31.48 & 84.5 & 111.3 & 39.9 & 24.0 & 26.5 & 22.8 & 484.6 \\
$\mathrm{n}=28$ & $(18.0)$ & $(12.9)$ & $(17.1)$ & $(15.0)$ & $(18.1)$ & \pm 8.1 & $(4.1)$ & \pm 4.6 & \pm 10.9 & \pm 64.94 \\
\hline $\begin{array}{c}\text { NO } \\
\mathrm{n}=13\end{array}$ & 51.0 & 74.3 & 29.2 & 84.0 & 111 & 39.6 & 24.5 & 25.2 & 20.3 & 516.6 \\
\hline $\mathrm{p}$ & .923 & $(17.8)$ & $(7.3)$ & $(32.5)$ & $(11.5)$ & \pm 7.5 & $(5.1)$ & \pm 2.9 & \pm 7.0 & \pm 65.1 \\
\hline $\begin{array}{c}\text { Actives } \\
\text { Opera }\end{array}$ & 45.5 & 70.75 & 27.0 & 82.65 & 103.4 & 36.8 & 24.5 & 26.9 & 22.2 & 509.23 \\
$\mathrm{n}=35$ & $(18.0)$ & $(17.4)$ & $(5.62)$ & $(13.7)$ & $(16.2)$ & \pm 7.4 & $(4.1)$ & \pm 5.6 & \pm 9.27 & \pm 58.91 \\
\hline NO & 51.0 & 76.1 & 31.3 & 84.25 & 111.5 & 39.87 & 24.4 & 26.2 & 22.17 & 492.6 \\
\hline $\mathrm{n}=15$ & $(17.5)$ & $(14.7)$ & $(6.6)$ & $(15.9)$ & $(16.4)$ & \pm 7.83 & $(3.9)$ & \pm 4.29 & \pm 10.1 & \pm 65.6 \\
\hline $\mathrm{p}$ & $.015^{*}$ & .429 & .675 & .747 & .675 & .835 & .116 & .145 & .297 & .251 \\
\hline
\end{tabular}

${ }^{*}=$ statistically significant difference; $p<0,05 ;$ age $=$ years; Sed. $=$ sedentary; opera=operated $\mathrm{BM}=$ body mass; $\mathrm{BMI}=$ body mass index; $\mathrm{WC}=$ waist circumference; $\mathrm{HC}=$ hip circumference; $\mathrm{F} \%=$ fat percentage; $\mathrm{SMM}=$ skeletal muscle mass; $\mathrm{GS}=$ grip strength $6 \mathrm{MWT}=6$ min walking test; FLEX=flexibility. Age, body mass, BMI, WC, $\mathrm{HC}$ e SMM are presented in median and interquartile amplitude. Time since surgery for the physically active operated group $=39,5(42,0)$. Time since surgery for the sedentary operated group $=46,0(102,0)$. Performed tests $=$ independent $t$ student test and $U$ of Mann-Whitney

Was observed that, according to the Table 3, there are statistically significant differences between the sedentary groups (operated and non-operated) when analyzed the following variables: body mass, $\mathrm{BMI}, \mathrm{WC}, \mathrm{HC}$, and $\mathrm{F} \%(\mathrm{p}=0,003, \mathrm{p}=0,004$, $p=0,045, p=0,028, p=0,034$ respectively). Of this variables, the highest indexes were found in the operated group, who presented median of the time since surgery of 46,0 (102).

\section{DISCUSSION}

Studies previously demonstrated that there is a reduction on the skeletal muscle mass and bone mass through the years after the bariatric surgery. This fact may cause complications such as the decrease of the daily energy expenditure and impacts on the bone metabolism ${ }^{5,8,31}$, and consequently a decrease of the physical activity indexes; however, this last influence was not observed in the present study.

In a review study ${ }^{10}$ was verified the bariatric surgery is considered as a good alternative concerning the body mass loss; nevertheless, it should be aware to the individuals age group, although the induced weight loss has been shown itself as efficient increasing the lifetime of severe obese patients.

On Table 2 is observed the grip strength presents a weak positive correlation with SMM $(r=0,159)$. In other hand, the 6MWT obtained a moderate negative correlation with $\mathrm{F} \%$ $(r=-0,445)$ and $\mathrm{BMI}(r=-367)$, and a weak negative correlation with $C(r=0,269)$ and body mass $(r=-0,213)$, demonstrating the relations between the body mass and the result obtained in the 6MWT. This data corroborate with another study with 43 obese that underwent to assessments both pre and post-late bariatric surgery, in which the results indicated that a high BMI negatively modulate the performance on the $6 \mathrm{MWT}^{4,27}$. In this sense, is possible to observe that in short-term, the bariatric surgery did not cause any negative impact on this variable.

The Table 3 indicates that the operated and non-operated sedentary group presented statistically significant differences to the variables: body mass, body mass index, waist circumference, hip circumference, and F\%. Regarding the both physically active operated and non-operated groups, was verified difference only on the variable age. Supporting these results, other studies made evident the relation between the regular practice of physical activity and an enhancement of the functional capacity and quality of life of operated patients ${ }^{12,14,21,25}$.

These results, corroborating with the ones in the scientific literature, indicate that Y-en-Roux by-pass with physical activities after the procedure, presents higher weight loss and enhance quality of life when compared to those considered inactive ${ }^{17}$. Santos et al. developed a prospective study in which were observed statistically significant differences in the adherence to the physical activity practice during the first 12 months post-operation. Although with sensible differences, it could be considered low frequency of physical practice regarding this specific population ${ }^{22}$

The statistical comparison analysis between the operated active groups $(n=35)$ and NO $(n=15)$ did not demonstrate significant differences between the groups on the anthropometric, body composition, and physical fitness variables. In other study ${ }^{28}$ was demonstrated that patients with severe obesity (BMI $43 \mathrm{~kg} / \mathrm{m}^{2}$ ), when underwent to a training post-surgery protocol, presented better maintenance and even increase in strength in comparison to their pairs who were not exposed to the same procedure. Was also observed in the same study a positive modulation of the aerobic and functional capacity assessed through the 6MWT.

The results on Table 3 confirm that the adoption of a healthy lifestyle, including the regular practice of physical activity contribute not only in the maintenance of the results acquired in the bariatric surgery ${ }^{19}$, but also enhance the general health conditions, and has an important role on the recuperation of the body mass lost during the first years after the surgery ${ }^{18}$.

In other hand, only the adoption of active habits during leisure time were seen as not enough to differ the groups regarding health-related physical fitness, functional capacity, and SMM. These parameters are very important to the age group of present study. However, the study demonstrated a positive impact on the anthropometric indexes between the operated sedentary group and NO, and of these parameters, $\mathrm{BMI}$ and WC - considered strong indicatives of cardiometabolic risk - being in the higher values observed in the sedentary operated group.

Is important to emphasize that the absence of statistically significant differences presented on the operated and nonoperated active groups may be related to the time after surgery in months in which the patients were (SAS $=61,0(114,5)$; $\mathrm{SUS}=38,0(30,0)$ months). These periods are characterized as body mass and BMI acute recuperation phases.

The literature indicates the highest body mass loss occurs between de $12^{\text {th }}$ and $18^{\text {th }}$ months after the procedure ${ }^{26}$. However, the results lead to a gradual body mass gain until the $6^{\text {th }}$ year after the surgery, followed by a weight stabilization, leading to reach the same situation before the surgery until $8^{\text {th }}$ year. This way, is understandable that the body mass dependent variables may also follow this trend, explaining the similarity between the operated and non-operated groups, equivalent in the other variables.

Were verified with the development of the present study that patients underwent to bariatric surgery that maintain physical activity health habits during the leisure period presents anthropometry, body composition, and physical fitness similar to a non-operated physically active group. However, the nonadoption of these health habits demonstrated a negative influence over the variables analyzed in the present study, because they present worse anthropometric and fat in comparison to those that did not performed the surgery. Thus, is emphasized the necessity of have health habits in order to keep the benefits acquired in the surgery procedure. 
CONCLUSION

There are no differences between the patients underwent to Y-en-Roux gastric bypass by the public health care, particular health insurance and an equivalent non-operated group in comparison to anthropometric, body composition and physical fitness variables. Nevertheless, these variables demonstrated differences between themselves, indicating that better anthropometric and body composition parameters are correlated to better physical fitness conditions on the analyzed variables.

\section{ACKNOWLEDGEMENT}

The authors thank 1) the financial support of the Brazilian Ministry of Health - Studies and Projects Sponsor (FINEP) by the permanent equipment; 2) the National Council for Scientific and Technological Development (CNPq) for the concession of a scientific initiation scholarship; and 3) the State University of Maringá for the physical space to perform the study.

\section{REFERENCES}

1. Bond DS, Phelan S, Wolfe LG, Evans RK, Meador JG, Kellum JM, et al Becoming physically active after bariatric surgery is associated with improved weight loss and health-related quality of life. Obesity (Silver Spring). 2009;17(1):78-83.

2. BrittoRR,SousaLAP.TestedecaminhadadeSeisMinutosUmaNormatização Brasileira. Fisioter em Mov. 2006;19(4):49-54.

3. Buchwald H, Oien DM. Metabolic/bariatric surgery worldwide 2011 Obes Surg. 2013;23(4):427-36.

4. Castello V, Simões RP, Bassi D, Catai AM, Arena R, Borghi-Silva A. Impact of aerobic exercise training on heart rate variability and functional capacity in obese women after gastric bypass surgery. Obes Surg. 2011;21(11):1739-49.

5. Costa TMRL, Paganoto M, Radominski RB, Zeghbi V, Borba C. Impact of deficient nutrition in bone mass after bariatric surgery. Arq Bras Cir Dig. 2016;29(1):38-42.

6. Fernandez M, Toimil RF, Rasslan Z, Ilias EJ, Gradinar AL, Malheiros CA Assessment of body fat in obese patients preoperatively for bariatric surgery. Arq Bras Cir Dig. 206;29Suppl (Suppl):59-6.

7. Ferreira C, Cohen L, Sarmento A, Monnerat F, Rosa M, Lopes E, et al Effects of long-term roux-en-y gastric bypass on body weight and clinical metabolic comorbidities in bariatric surgery service of a university hospital. 2016;29 (Suppl. 1):20-3.

8. Gene Carey D, Pliego G, Raymond R, Brooke Skau K. Body Composition and Metabolic Changes Following Bariatric Surgery: Effects on Fat Mass, Lean Mass and Basal Metabolic Rate. Obes Surg. 2006;16(4):469-77.

9. Guedes DP. Manual prático para avaliação em educação física. Editora Manole Ltda; 2006.

10. Han TS, Tajar A, Lean MEJ. Obesity and weight management in the elderly. Br Med Bull. 2011;97(1):169-96.

11. HartwigTW, dosSAntosFAI, GonzálezMC, RombaldiAJ.Effects ofbariatric surgeryon the body composition of adults. Braszlian J Kinanthropometry HumPerform [Internet].2013;9(390):1251-5.Availablefrom:http://www. ncbi.nlm.nih.gov/pubmed/23821842
12. Herring LY, Stevinson C, Davies MJ, Biddle SJ, Sutton C, Bowrey D, et al. Changes in physical activity behaviourand physical function afterbariatric surgery: a systematic review and meta-analysis. Obes Rev [Internet] 2016;(4):n/a-n/a.Availablefrom:http://doi.wiley.com/10.1111/obr.12361

13. Heyward V. Asep methods recommendation: body composition assessment. J Exerc Physiol online. 2001;1971-9751(1):1-10.

14. Huck CJ. Effects of Supervised Resistance Training on Fitness and Functional Strength in Patients Succeeding Bariatric Surgery. J Strength Cond Res. 2015;29(3):589-95.

15. IBGE.PesquisadeOrçamentosFamiliares2008-2009:Despesas, Rendimentos eCondições deVida.BibliotecadoMinisteriodoPlanejamento,Orçamento e Gestão. 2010. 1-222 p.

16. Kolotkin RL, LaMonte MJ, Litwin S, Crosby RD, Gress RE, Yanowitz FG, et al. Cardiorespiratory fitness and health-related quality of life in bariatric surgery patients. Obes Surg. 2011;21(4):457-64.

17. Larsson I, Lissner L, Naslund I, Lindroos AK. Leisure and occupational physical activity in relation to body mass index in men and women. Scand J Nutr. 2004;48(4):165-72.

18. Mcgrice M. Interventions to improve long-term weight loss in patients following bariatric surgery : challenges and solutions. 2015;263-74.

19. Nassif DSB, Nassif PAN, Lucas RWDC, Ribas-Filho JM, Czeczko NG, KalilFilho FA, et al. Efeito da fisioterapia contra-resistida com relação à massa corporal magra em pacientes no pós-operatório de cirurgia bariátrica. ABCD Arq Bras Cir Dig (São Paulo). 2011;24(3):218-25.

20. Oliveira JJ de, Freitas ACT de, Almeida AA de. Postoperative effect of physical therapy related to functional capacity and respiratory muscle strength in patients submitted to bariatric surgery. ABCD Arq Bras Cir Dig. 2016;29(1):43-7.

21. Pouwels S, WitM, TeijinkJAW, Nienhuijs SW. Aspects of exercise before or after bariatric surgery: A systematic review. Obes Facts. 2015;8(2):132-46

22. Ramos RJ, Mottin CC, Alves LB, Benzano D, Alexandre Vontobel P. Effect of size of intestinal diversions in obese patients with metabolic syndrome submitted to gastric bypass. ABCD Arq Bras Cir Dig. 2016;29(1):15-9.

23. Rico Hernández MA, Martínez Sancho E, Armero Fuster M, Díaz Gómez J, Calvo Viñuela I. Comparación a 5 años de dos técnicas de cirugía bariátrica en pacientes con obesidad mórbida seguidos en consulta enfermera. Nutr Hosp. 2009;24(6):667-75.

24. Santos LMP, De Oliveira IV, Peters LR, Conde WL. Trends in morbid obesity and in bariatric surgeries covered by the Brazilian public health system. Obes Surg. 2010;20(7):943-8.

25. Shah M, Snell PG, Rao S, Adams-huet B, Quittner C, Livingston EH, et al. High-Volume Exercise Program in Obese Bariatric Surgery Patients : A Randomized, Controlled Trial. Obesity. Nature Publishing Group; 2009;19(9):1826-34

26. Sjöström L, Lindroos A-K, Peltonen M, Torgerson J, Bouchard C, Carlsson $B$, et al. Lifestyle, diabetes, and cardiovascular risk factors 10 years after bariatric surgery. NEnglJ Med. Mass Medical Soc;2004;351(26):2683-93.

27. Socool FB, Peruzzo SS, Mortari D, Scortegagna G, Sbruzzi G, Santos $\mathrm{PC}$, et al. Prevalência de artralgia em indivíduos obesos no pré e pósoperatório tardio de cirurgia bariátrica. 2009;69-74.

28. Stegen S, Derave W, Calders P, Van Laethem C, Pattyn P. Physical fitness in morbidly obese patients: Effect of gastric bypass surgery and exercise training. Obes Surg. 2011;21(1):61-70.

29. Veloso AP, Cusmanich KG. Evaluation of the thoracoabdominal mobility of obese subjects in pre-bariatric surgery. Arq Bras Cir Dig. 206;29Suppl 1(Suppl 1):39-42.

30. Veloso APLR, Cusmanich KG. Avaliação da mobilidade toracoabdominal dos obesos no pré-operatório de cirurgia bariátrica. ABCD Arq Bras Cir Dig. 2016;29(1):39-42.

31. Von Mach M, Stoeckli R, Bilz S, Kraenzlin M, Langer I, Keller U. Changes in bone mineral content after surgical treatment of morbid obesity. Metabolism. 2004:53(7):918-21.

32. Word Health Organization. Media centre Obesity and overweight. 2015. p. 1-5. 